\title{
28 Research Square \\ Desquamation In Kawasaki Disease And Its Relationship With Coronary Artery Abnormalities
}

\author{
JIAHUEI YAN \\ Chang-Gung Memorial hospital https://orcid.org/0000-0003-0023-2672 \\ Wan-Shan Lo \\ Chang Gung Memorial Hospital \\ Mindy Ming-Huey Guo \\ Chang Gung Memorial Hospital \\ Ying-Hsien Huang \\ Chang Gung Memorial Hospital \\ Ling-Sai Chang \\ Chang Gung Memorial Hospital \\ Ho-Chang Kuo ( $\nabla$ erickuo48@yahoo.com.tw ) \\ https://orcid.org/0000-0002-3295-2984
}

\section{Research article}

Keywords: Desquamation, coronary artery lesion, Kawasaki disease

Posted Date: April 29th, 2020

DOI: https://doi.org/10.21203/rs.3.rs-24866/v1

License: (c) (i) This work is licensed under a Creative Commons Attribution 4.0 International License. Read Full License 


\section{Abstract}

Background Desquamation of hands and feet is a common characteristic of Kawasaki disease (KD), and occurs in $68-98 \%$ of patients diagnosed with KD. In this study, we analyzed patients' varying desquamation levels in their hands or feet, in correlation with clinical presentation, to assess the relationship.

Method We retrospectively reviewed children with KD who had follow-up visits in Kaohsiung Chang Gung Memorial Hospital's pediatric outpatient department (OPD) during 2018 and 2019. We analyzed their age, laboratory data before intravenous immunoglobulin (IVIG) treatment, and coronary artery abnormalities (CAA) based on the desquamation level of their hands and feet.

Results We enrolled a total 112 patients in the study, and 92 patients (82.1\%) had hand or feet desquamation. We found the hands' high-grade desquamation was positively associated with age and segmented neutrophil percentage ( $p=0.047$ and 0.029 , respectively) but negatively associated with lymphocyte and monocyte percentage $(p=0.03$ and 0.006 , respectively). Meanwhile, the feet's high-grade desquamation was positively associated with total white blood cell count $(p=0.033)$. Furthermore, we found that high-grade hand desquamation had less probability of CAA formation compared with that of a low grade $(7.1 \%$ vs. $40.8 \%, p=0.016)$. We observed no significant difference in IVIG resistance between the groups.

Conclusion This report is the first to demonstrate that the desquamation level of hands or feet in Kawasaki disease is associated with different coronary artery abnormalities and laboratory findings. Physicians should be cautious of CAA formation, particularly in patients with low-grade hand peeling.

\section{Background}

Kawasaki disease (KD) is a form of acute febrile vasculitis that primarily affects children under the age of 5 years old, particularly those of Asian descent. KD could cause coronary artery dilatation or aneurysm formation if treatment is not received in a timely manner. KD is characterized by prolonged fever of more than 5 days, as well as four of the following five typical features: bilateral non-exudative conjunctivitis, oral changes (erythema in lip or oropharyngeal mucosa, strawberry tongue, fissure lip), cervical lymphadenopathy, skin rash, and changes in extremities [1]. While KD has been suggested to have an infectious association and gene susceptibility, no consistent causative pathogen was identified, and the etiology is still not well understood. The affected coronary arteries undergo an inflammatory process with neutrophilic infiltration, upregulation of cytotoxic $T$ cells, and myofibroblastic proliferation, which pushes coronary arteries to stenosis [2, 3]. While some coronary changes may resolve within 1 to 2 years [1], pediatricians are concerned some may remain life-long sequalae.

The desquamation of hands and feet, which may extend to palms and soles, is a subacute phase of extremity change and usually occurs 2 to 3 weeks after fever onset [1]. According to a number of studies, the prevalence of periungual peeling ranges from 68-98\% [4-6]. The pathogenesis of desquamation in KD is not clear, but previous studies have shown the association between skin peeling with clinical signs and laboratory findings [6, 7].

Nevertheless, researchers have not compared the clinical presentation with the severity of desquamation in KD. In this study, we aimed to assess the level of hand and foot desquamation, from fingertips (toes) to palm (sole) and compare them with their clinical characteristics in case studies.

\section{Method}


We retrospectively reviewed children with KD who had follow-up visits in Kaohsiung Chang Gung Memorial Hospital's pediatric outpatient department during 2018 to 2019. Patients who were treated in another hospital during the acute phase or cases with incomplete medical records were excluded. KD was diagnosed in accordance with the American Heart Association (AHA) criteria, which includes fever for more than 5 days and typically having four of five clinical features (bilateral non-exudative conjunctivitis, oral changes, cervical lymphadenopathy (> $1.5 \mathrm{~cm}$ in diameter), hand and feet edema or desquamation, and polymorphism skin rash), while incomplete KD was diagnosed as prolonged fever and two or three clinical features, plus CRP $\geq 30 \mathrm{mg} / \mathrm{L}$ and/or ESR $\geq$ $40 \mathrm{~mm} /$ hour and supplemental laboratory data (anemia by age, platelet count $\geq 450000 / \mathrm{mm}^{3}$ after 7 th day of fever, albumin $\leq 3 \mathrm{~g} / \mathrm{dL}$, elevated ALT level, WBC count $\geq 15000 / \mathrm{mm}^{3}$, urine $\geq 10 \mathrm{WBC} /$ high power field) or echocardiography findings. Coronary artery abnormalities (CAA) are defined as: (1) left anterior descending (LAD) coronary artery or right coronary artery (RCA) Z score of $\geq 2.5$; (2) coronary artery aneurysm; (3) the presence of $\geq$ 3 other suggestive features, including decreased left ventricular function, mitral regurgitation, pericardial effusion, Z scores in LAD coronary artery, or RCA of 2 to 2.5 [1]. IVIG resistance was defined as persistent fever at least 48 hours after initial IVIG therapy where a second IVIG infusion had to be administered to patients.

We classified groups into desquamation positive or not and then further divided into "hand desquamation" and "foot desquamation". We provided an illustration (Fig. 1) to identify the desquamation grade. In hands and feet, a classified number of 0 meant no desquamation, while 1 to 3 represented fingertip (toe tip), between fingertip (toe tip) and palm (sole) (Figs. 2 and 3). High-grade desquamation was defined as levels 2 and 3, while low-grade referred to level 1 (limited to fingertips or toe tips). Patients were divided into groups according to "desquamation or not" and "desquamation grades". We analyzed patients' age and laboratory data within 3 days prior to the administration of intravenous immunoglobulin (IVIG) and follow-up echocardiography series from admission to 1 to 2 years after disease onset. This study was approved by the Institutional Review Board of Chang Gung Memorial Hospital (201600714A3).

We performed the Kolmogorov-Smirnova test to examine data distribution, the Kruskal-Wallis and Mann-Whitney tests for continuous variable analysis, and the Chi-square test for categorical variables. To determine the cut-off value, we used the receiver operating characteristic (ROC) curve, Youden index, and minimal distance. Data are presented as percentage and median with interquartile range (IQR). Results were considered statically significant when p-values < 0.05. All statistical analysis was performed using SPSS 22.0 (SPSS, Inc., Chicago, Illinois).

\section{Results}

This study included a total of 112 patients, and 92 of them (82.1\%) had hand or foot desquamation. The laboratory data and IVIG resistant rate demonstrated no significant difference between patients with and those without desquamation (Table 1). We further analyzed data based on "hand desquamation" and "foot desquamation". In both categories, we further classified into sub-groups according to "Desquamation positive or negative" and "High-grade or low-grade" (Tables 2 and 3). 
Table 1

Patients' laboratory data - with or without desquamation

\begin{tabular}{|llll|}
\hline & Without desquamation & With desquamation & P value \\
\hline Total & $20(17.9 \%)$ & $92(82.1 \%)$ & \\
\hline Male gender & $14 / 20(70.0 \%)$ & $52 / 92(56.5 \%)$ & 0.322 \\
\hline Age & $1.1(0.6-1.6)$ & $1.4(0.8-2.6)$ & 0.063 \\
\hline WBC (1000/mm $\left.{ }^{3}\right)$ & $12.7(9.7-16.4)$ & $12.5(10.1-14.4)$ & 0.536 \\
\hline Hemoglobulin(g/dL) & $11.0(10.3-11.9)$ & $11.1(10.3-12.0)$ & 0.811 \\
\hline Platelet $\left(1000 / \mathrm{mm}^{3}\right)$ & $333.0(253.5-434.8)$ & $361.0(285.5-435.8)$ & 0.416 \\
\hline Segmented WBC(\%) & $53.7(45.0-65.6)$ & $61.0(47.1-72.0)$ & 0.173 \\
\hline Band WBC(\%) & $0(0-0)$ & $0(0-0)$ & 1.000 \\
\hline Lymphocyte $(\%)$ & $29.2(25.4-45.1)$ & $29.2(20.0-40.0)$ & 0.368 \\
\hline Monocyte $(\%)$ & $7.1(3.2-10.1)$ & $5.0(3.8-8.0)$ & 0.277 \\
\hline CRP (mg/L) & $35.8(14.7-64.0)$ & $58.4(28.6-116.1)$ & 0.078 \\
\hline AST (IU/L) & $42.0(32.5-62.8)$ & $35.0(25.0-75.0)$ & 0.342 \\
\hline ALT (IU/L) & $23.5(16.0-93.3)$ & $45.0(18.0-92.8)$ & 0.268 \\
\hline Albumin $(\mathrm{g} / \mathrm{dL})$ & $4.0(3.5-4.3)$ & $3.9(3.6-4.2)$ & 0.852 \\
\hline Urine WBC $(/ \mu \mathrm{L})$ & $3.0(0-34.0)$ & $6.0(0-24.0)$ & 0.950 \\
\hline IVIG resistant rate & $1 / 20(5.0 \%)$ & $6 / 92(6.5 \%)$ & 1.000 \\
\hline
\end{tabular}


Table 2

Patients' laboratory data-Hands' Desquamation before IVIG

\begin{tabular}{|c|c|c|c|c|c|c|}
\hline & $\begin{array}{l}\text { Hands' } \\
\text { desquamation } \\
\text { negative }\end{array}$ & $\begin{array}{l}\text { Hands' } \\
\text { desquamation } \\
\text { positive }\end{array}$ & $\begin{array}{l}P \\
\text { value }\end{array}$ & $\begin{array}{l}\text { Low-grade } \\
\text { desquamation }\end{array}$ & $\begin{array}{l}\text { High-grade } \\
\text { desquamation }\end{array}$ & $\begin{array}{l}\mathrm{P} \\
\text { value }\end{array}$ \\
\hline Total & 21 & 91 & & 77 & 14 & \\
\hline Male gender & $14 / 21(66.7 \%)$ & $52 / 91(57.1 \%)$ & 0.470 & $44 / 77(57.1 \%)$ & $8 / 14(57.1 \%)$ & 1.000 \\
\hline Age & $1.0(0.6-1.6)$ & $1.5(0.7-2.6)$ & $0.046 *$ & $1.4(0.7-2.5)$ & $2.2(1.3-4.2)$ & 0.047 \\
\hline WBC $\left(1000 / \mathrm{mm}^{3}\right)$ & $\begin{array}{l}12.4(9.8- \\
16.2)\end{array}$ & $\begin{array}{l}\text { 12.5(10.1- } \\
14.4)\end{array}$ & 0.568 & $\begin{array}{l}12.5(9.8- \\
14.4)\end{array}$ & $\begin{array}{l}12.4(11.4- \\
14.8)\end{array}$ & 0.46 \\
\hline Hemoglobulin(g/dL) & $\begin{array}{l}10.7(10.3- \\
11.9)\end{array}$ & $11.1(10.3-12)$ & 0.723 & $11.1(10.2-12)$ & $\begin{array}{l}11.2(10.3- \\
11.8)\end{array}$ & 0.697 \\
\hline $\begin{array}{l}\text { Platelet } \\
\left(1000 / \mathrm{mm}^{3}\right)\end{array}$ & $\begin{array}{l}341.0(254.0- \\
433.5)\end{array}$ & $\begin{array}{l}360.0(284.0- \\
437.0)\end{array}$ & 0.519 & $\begin{array}{l}352.0(287.0- \\
431.0)\end{array}$ & $\begin{array}{l}365.5(262.3- \\
447.0)\end{array}$ & 0.98 \\
\hline Segmented WBC(\%) & $\begin{array}{l}51.3(45.3- \\
65.3)\end{array}$ & $\begin{array}{l}\text { 61.0(48.1- } \\
72.0)\end{array}$ & 0.123 & $\begin{array}{l}59.0(46.2- \\
70.7)\end{array}$ & $\begin{array}{l}69.8(60.7- \\
76.8)\end{array}$ & 0.029 \\
\hline Band WBC(\%) & $0(0-0)$ & $0(0-0)$ & 0.900 & $0(0-0)$ & $0(0-1)$ & 0.702 \\
\hline Lymphocyte (\%) & $\begin{array}{l}29.7(25.6- \\
45.7)\end{array}$ & $\begin{array}{l}29.1(20.0- \\
40.0)\end{array}$ & 0.236 & $\begin{array}{l}30.0(21.6- \\
40.1)\end{array}$ & $\begin{array}{l}20.1(14.6- \\
31.1)\end{array}$ & 0.03 \\
\hline Monocyte (\%) & $7.0(3.1-9.7)$ & $5.0(3.9-8.0)$ & 0.412 & $5.5(4.0-8.9)$ & $4.1(2.8-4.9)$ & 0.006 \\
\hline CRP (mg/L) & $\begin{array}{l}37.4(15.3- \\
65.0)\end{array}$ & $\begin{array}{l}58.2(28.1- \\
115.1)\end{array}$ & 0.145 & $\begin{array}{l}57.7(29.0- \\
104.5)\end{array}$ & $\begin{array}{l}\text { 101.3(22.2- } \\
177.3)\end{array}$ & 0.324 \\
\hline AST (IU/L) & $\begin{array}{l}42.0(34.0- \\
86.0)\end{array}$ & $\begin{array}{l}35.0(25.0- \\
69.8)\end{array}$ & 0.214 & $\begin{array}{l}35.0(26.0- \\
64.5)\end{array}$ & $\begin{array}{l}34.0(25.0- \\
178.5)\end{array}$ & 0.923 \\
\hline ALT (IU/L) & $\begin{array}{l}24.0(16.0- \\
95.0)\end{array}$ & $\begin{array}{l}43.0(18.0- \\
88.0)\end{array}$ & 0.395 & $\begin{array}{l}39.0(18.3- \\
82.5)\end{array}$ & $\begin{array}{l}55.0(15.0- \\
237.0)\end{array}$ & 0.935 \\
\hline Albumin $(\mathrm{g} / \mathrm{dL})$ & $4.0(3.5-4.3)$ & $3.9(3.6-4.2)$ & 0.852 & $3.9(3.5-4.2)$ & $4.1(3.9-4.4)$ & 0.07 \\
\hline Urine WBC $(/ \mu \mathrm{L})$ & $3.0(0-28.5)$ & $6.0(0-24.0)$ & 0.817 & $6.0(0-21.0)$ & $6.0(0-145.5)$ & 0.395 \\
\hline IVIG resistant rate & $1 / 21(4.8 \%)$ & $6 / 91(6.6 \%)$ & 1.000 & $5 / 77(6.5 \%)$ & $1 / 14(7.1 \%)$ & 1.000 \\
\hline
\end{tabular}


Table 3

Patients' laboratory data-Feet's Desquamation before IVIG

\begin{tabular}{|c|c|c|c|c|c|c|}
\hline & $\begin{array}{l}\text { Feet's } \\
\text { desquamation } \\
\text { negative }\end{array}$ & $\begin{array}{l}\text { Feet's } \\
\text { desquamation } \\
\text { positive }\end{array}$ & $\begin{array}{l}P \\
\text { value }\end{array}$ & $\begin{array}{l}\text { Low-grade } \\
\text { desquamation }\end{array}$ & $\begin{array}{l}\text { High-grade } \\
\text { desquamation }\end{array}$ & $\begin{array}{l}P \\
\text { value }\end{array}$ \\
\hline Total & 39 & 63 & & 54 & 9 & \\
\hline Male gender & $27 / 39(69.2 \%)$ & $32 / 63(50.8 \%)$ & 0.067 & $27 / 54(50.0 \%)$ & $5 / 9(55.6 \%)$ & 1.000 \\
\hline Age & $1.1(0.7-1.9)$ & $1.6(0.7-2.5)$ & 0.185 & $1.6(0.7-2.2)$ & $1.4(1.1-3.6)$ & 0.327 \\
\hline WBC $\left(1000 / \mathrm{mm}^{3}\right)$ & $\begin{array}{l}11.3(9.2- \\
15.2)\end{array}$ & $\begin{array}{l}12.5(10.5- \\
14.4)\end{array}$ & 0.610 & $\begin{array}{l}12.3(10.2- \\
14.0)\end{array}$ & $\begin{array}{l}14.0(12.8- \\
17.0)\end{array}$ & 0.033 \\
\hline Hemoglobulin(g/dL) & $\begin{array}{l}11.3(10.3- \\
12.0)\end{array}$ & $\begin{array}{l}10.9(10.2- \\
11.7)\end{array}$ & 0.484 & $\begin{array}{l}10.9(10.2- \\
11.9)\end{array}$ & $\begin{array}{l}10.7(10.2- \\
11.7)\end{array}$ & 0.746 \\
\hline $\begin{array}{l}\text { Platelet } \\
\left(1000 / \mathrm{mm}^{3}\right)\end{array}$ & $\begin{array}{l}325.0(255.0- \\
431.0)\end{array}$ & $\begin{array}{l}375.0(299.0- \\
441.0)\end{array}$ & 0.094 & $\begin{array}{l}376.5(297.3- \\
442.3)\end{array}$ & $\begin{array}{l}371.0(313.0- \\
449.5)\end{array}$ & 0.912 \\
\hline Segmented WBC(\%) & $\begin{array}{l}56.2(44.6- \\
68.0)\end{array}$ & $\begin{array}{l}62.0(51.0- \\
72.0)\end{array}$ & 0.300 & $\begin{array}{l}61.0(49.8- \\
69.8)\end{array}$ & $\begin{array}{l}63.0(58.4- \\
74.3)\end{array}$ & 0.249 \\
\hline Band WBC(\%) & $0(0-0)$ & $0(0-0)$ & 0.961 & $0(0-0)$ & $0(0-0)$ & 0.528 \\
\hline Lymphocyte (\%) & $\begin{array}{l}29.7(20.0- \\
44.3)\end{array}$ & $\begin{array}{l}29.0(21.2- \\
39.0)\end{array}$ & 0.498 & $\begin{array}{l}28.5(21.8- \\
39.3)\end{array}$ & $29(16.9-33.3)$ & 0.539 \\
\hline Monocyte (\%) & $7.0(3.8-10.0)$ & $4.7(3.1-7.0)$ & 0.070 & $5.0(3.4-7.9)$ & $4.0(3.0-4.8)$ & 0.098 \\
\hline CRP (mg/L) & $\begin{array}{l}39.3(14.1- \\
67.6)\end{array}$ & $\begin{array}{l}58.3(32.1- \\
122.1)\end{array}$ & $0.023^{*}$ & $\begin{array}{l}58.3(32.1- \\
119.8)\end{array}$ & $\begin{array}{l}76.3(29.3- \\
179.7)\end{array}$ & 0.845 \\
\hline AST (IU/L) & $\begin{array}{l}42.5(32.3- \\
93.5)\end{array}$ & $\begin{array}{l}34.0(25.0- \\
68.5)\end{array}$ & $0.045^{*}$ & $\begin{array}{l}34.0(25.5- \\
99.5)\end{array}$ & $\begin{array}{l}25.0(21.0- \\
47.0)\end{array}$ & 0.155 \\
\hline ALT (IU/L) & $\begin{array}{l}34.5(18.0- \\
107.3)\end{array}$ & $\begin{array}{l}38.5(17.0- \\
74.3)\end{array}$ & 0.635 & $\begin{array}{l}47.5(17.8- \\
77.3)\end{array}$ & $\begin{array}{l}23.5(14.0- \\
71.0)\end{array}$ & 0.495 \\
\hline Albumin (g/dL) & $3.9(3.5-4.3)$ & $4.0(3.6-4.2)$ & 0.905 & $4.0(3.6-4.2)$ & $4.0(3.6-4.4)$ & 0.469 \\
\hline Urine WBC $(/ \mu \mathrm{L})$ & $3.0(0-34.0)$ & $6.0(0-24.3)$ & 0.763 & $6.0(0-21.8)$ & $4.5(0-142.8)$ & 0.931 \\
\hline IVIG resistant rate & $2 / 39(5.1 \%)$ & $4 / 63(6.3 \%)$ & 1.000 & $4 / 54$ & $0 / 9$ & 1.000 \\
\hline${ }^{*} p<0.05$ & & & & & & \\
\hline
\end{tabular}

In the "hand desquamation" group (Table 2), 91 patients were positive for hand desquamation, and the distribution of grades 1 , and 3 were 77,7 , and 7 cases, respectively. We found older age to be related to a positive desquamation finding $(p=0.046)$. Furthermore, older age $(p=0.047)$, elevated segmented white blood cell (WBC) percentage $(p=0.029)$, lower lymphocyte $(p=0.03)$, and lower monocyte $(p=0.006)$ percentage were all associated with high-grade desquamation. Regarding age, the area under the curve (AUC) of hand desquamation positive is 0.64 (Fig. 4), with an optimal cut-off value of 2 years old. The desquamation positive rate was $97 \%$ ( $\geqq 2$ years old) and $74.7 \%(<2$ years old $)$, respectively $(p=0.006)$. 
In the "foot desquamation" group (Table 3), 63 patients were positive for foot desquamation, and the distribution of grades 1,2, and 3 were 54,2 , and 7 cases, respectively. The desquamation positive group had higher $\mathrm{C}$-reactive protein (CRP) but lower aspartate transaminase (AST) levels ( $p=0.023$ and 0.045 , respectively), while the highgrade desquamation group had a higher WBC count $(p=0.033)$. We observed no significant difference in the IVIGresistant rate between hand and foot desquamation.

With regard to coronary artery abnormalities (CAA), the total desquamation and hand and foot desquamation incidences were similar in patients with CAA and those without (Table 4). We further analyzed the subgroups and found that patients with CAA formation had a significantly lower incidence of only $3 \%$ accompanied with highgrade hand desquamation $(p=0.016)$. Furthermore, high-grade hand peeling had a decreased incidence of CAA formation than low-grade hand peeling $(7.1 \%$ vs. $40.8 \%, p=0.016)$ in two-year series echocardiography, while we had no significant finding in the feet subgroups.

Table 4

CAA formation incidence in subgroups

\begin{tabular}{|c|c|c|c|}
\hline & $\operatorname{CAA}(-)$ & CAA (+) & $P$ value \\
\hline Total desquamation $(+)$ & $59 / 71(83.1 \%)$ & $33 / 41(80.5 \%)$ & 0.800 \\
\hline \multicolumn{4}{|l|}{ Hands } \\
\hline Desquamation (+) & $58 / 71(81.7 \%)$ & $33 / 41(80.5 \%)$ & 1.000 \\
\hline High-grade & 13/58(22.4\%) & 1/33(3.0\%) & $0.016 *$ \\
\hline \multicolumn{4}{|l|}{ Feet } \\
\hline Desquamation $(+)$ & $42 / 67(62.7 \%)$ & $21 / 35(60.0 \%)$ & 0.832 \\
\hline High-grade & $8 / 42(19.0 \%)$ & $1 / 21(4.5 \%)$ & 0.159 \\
\hline
\end{tabular}

\section{Discussion}

To the best of our knowledge, this study is the first to discuss different levels of desquamation associated with the clinical symptoms and signs of KD. Epidermal turnover and desquamation are natural processes in mammals [8], but some diseases may progress these processes. For example, the toxin secreted by Staphylococcus aureus is related to the cleavage of keratinocyte junction and cell-to-cell adhesion in the epidermis [9], which may cause Staphylococcus aureus scalded skin syndrome. The activation of cutaneous $T$ cells induced by the superantigen of streptococcus results in upregulating skin-homing capacity, and the rash of scarlet fever is followed by peeling in response to cytokine release and activated T-cell infiltration [10]. Hand-foot-mouth disease caused by the enterovirus also contributes to skin desquamation, but the related pathophysiology remains poorly understood [11, 12]. The characteristics of common pediatric diseases involving fever and desquamation are compared in Table 5 $[7,11,13-20]$. 
Table 5

The characteristics of common pediatrics diseases involving fever and desquamation

\begin{tabular}{|c|c|c|c|c|}
\hline Disease & $\begin{array}{l}\text { Kawasaki disease } \\
\text { (KD) }\end{array}$ & $\begin{array}{l}\text { Staphylococcal scalded skin } \\
\text { syndrome (SSSS) }\end{array}$ & $\begin{array}{l}\text { Hand, foot, and } \\
\text { mouth disease } \\
\text { (HFMD) }\end{array}$ & Scarlet fever \\
\hline Pathogen & unknown & Staphylococcus aureus & Enterovirus & $\begin{array}{l}\text { Group A } \\
\text { streptococcus }\end{array}$ \\
\hline \multirow[t]{2}{*}{$\begin{array}{l}\text { Clinical } \\
\text { features of } \\
\text { desquamation }\end{array}$} & $\begin{array}{l}\text { Periungual, start } \\
\text { at the tips of } \\
\text { fingers and toes, } \\
\text { often multiple-- } \\
\text { digits involvement }\end{array}$ & $\begin{array}{l}\text { The erythema and blister } \\
\text { typically start on the face and } \\
\text { flexures (groin, axillae, neck), } \\
\text { follow by desquamation on } \\
\text { bullae sites }\end{array}$ & $\begin{array}{l}\text { Small vesicles } \\
\text { and papules of } \\
\text { the distal } \\
\text { extremities and } \\
\text { buttocks }\end{array}$ & $\begin{array}{l}\text { Rashes with } \\
\text { sandpaper } \\
\text { texture, start on } \\
\text { the trunk and } \\
\text { spreads out }\end{array}$ \\
\hline & $\begin{array}{l}\text { Perineal } \\
\text { desquamation }\end{array}$ & & $\begin{array}{l}\text { Desquamation } \\
\text { often found at } \\
\text { the sites of } \\
\text { rashes, palms } \\
\text { and soles }\end{array}$ & $\begin{array}{l}\text { Pastia's lines* } \\
\text { Desquamation } \\
\text { follows after } \\
\text { skin rash }\end{array}$ \\
\hline
\end{tabular}

Hand and foot desquamation have distinct characteristics in this study. The desquamation in KD mostly occurred during the convalescent phase of the disease [21]. We did not observe any significant difference in the laboratory findings between patients with and those without desquamation. However, we further classified patients into hand or foot desquamation and began to observe differences. Hand desquamation was associated with older age, and high-grade hand peeling was related to older age, elevated segmented WBC percentage, and lower lymphocyte and monocyte percentages. Meanwhile, foot desquamation was associated with elevated CRP and AST, and high-grade foot desquamation was related to increased WBC count. In the AHA diagnosis criteria of atypical KD, supplemental laboratory tests include WBC count, CRP, and ALT level, all of which indicate the inflammation status of KD. Wang et al. revealed desquamation positive KD patients had lower WBC counts, higher band-form percentage, and elevated ALT level, but the age, gender, percentage neutrophils, hemoglobulin, CRP, and platelet count were similar [6]. In another study analyzing desquamation in KD, Kim et al. revealed that patients with desquamation had higher platelet counts and elevated AST and ALT [7]. In our study, the WBC counts were only associated with high-level foot desquamation; in contrast, higher AST levels were negatively related to foot desquamation. Both the bandform percentage and ALT level were similar in our subgroups. The two aforementioned studies did not further discuss differences in laboratory findings in peeling severity in either the hands or the feet.

Interestingly, we found that high-grade hand peeling was related to a decreased incidence of CAA formation. Kim et al. showed no difference between groups with or without desquamation regarding coronary artery lesions [7]. However, Wang et al. also indicated that cases who did not peel had a higher probability of aneurysm formation [6], and another study revealed that recurrent skin peeling in KD was significantly less frequent in patients with coronary dilatation or aneurysm formation [22]. Desquamation seems to have a protective effect on CAA formation. Although the mechanism is not clear, we suppose that the more cytokines released to facilitate skin peeling, the fewer inflammatory factors in coronary arteries. Further research is required to identify the pathophysiology.

This study had certain limitations. We conducted a retrospective review of medical records, and some cases of desquamation were identified based on the reporting of family history, both of which may have recall bias and 
variable accuracy. Furthermore, this study was a single center experience, which is not sufficient for reflecting the general condition nationwide. As for CAA formation, some patients who were diagnosed as having KD under

2 years of age, a longer echocardiography is needed to observe coronary artery changes. Both multi-center studies and longer follow-up times are needed to analyze the various grades of desquamation in KD with clinical features.

\section{Conclusion}

This report is the first to study various severities of hand and foot periungual desquamation in KD associated with coronary artery abnormalities. Pediatricians should be aware of prolonged fever and periungual desquamation with unknown origin. Furthermore, the risk of coronary artery changes cannot be overlooked, and we should be particularly cautious with those who have low-grade hand desquamation in KD.

\section{Abbreviations}

KD

Kawasaki disease; AHA:American Heart Association; CRP:C-reactive protein; ESR:Erythrocyte sedimentation rate; AST:Aspartate Aminotransferase; ALT:Alanine Aminotransferase; WBC:White blood cell; CAA:Coronary artery abnormalities; LAD:left anterior descending artery; RCA:right coronary artery; IVIG:intravenous immunoglobulin; ROC curve:receiver operating characteristic curve; IQR:interquartile range; AUC:area under the curve; SSSS:Staphylococcal scalded skin syndrome; HFMD:Hand, foot, and mouth disease

\section{Declarations}

\section{Ethics approval and consent to participate}

This study was approved the Institutional Review Board of Chang Gung Memorial Hospital (201600714A3)

\section{Consent for publication}

Not applicable

\section{Availability of data and materials}

The datasets generated and analyzed during the current study are not publicly available due to strict ethical regulation of information privacy in Taiwan. The consent to participate does not include permission to make the data available to a third party

\section{Competing interests}

The corresponding author Dr. Ho-Chang Kuo is one of the associate editor of BMC Pediatrics.

\section{Funding}

This study received funding from the following grants: MOST 108-2314-B-182 -037 -MY3 and MOST 103-2410-H264-004 from the Ministry of Science and Technology of Taiwan and 8E0212 from Chang Gung Memorial Hospital in Taiwan. Although these institutes provided financial support, they had no influence on the way in which we collected, analyzed, or interpreted the data or wrote this manuscript. 


\section{Authors' contributions}

All authors were involved in drafting the article or revising it critically and all authors approved the final version to be published. MG, YH and WL contributed to conceptualization and study design of the study; JY and WL interpreted and statistically analyzed the data; JY was the major contributor in writing the manuscript. LC and HK were responsible for monitoring and data management, reviewing and editing the manuscript.

\section{Acknowledgements}

We would like to thank the Biostatistics Center, Kaohsiung Chang Gung Memorial Hospital for its statistical work.

\section{References}

1. McCrindle BW, Rowley AH, Newburger JW, Burns JC, Bolger AF, Gewitz M, Baker AL, Jackson MA, Takahashi M, Shah PB, et al. Diagnosis, Treatment, and Long-Term Management of Kawasaki Disease: A Scientific Statement for Health Professionals From the American Heart Association. Circulation. 2017;135(17):e927-99.

2. Rowley AH, Shulman ST. The Epidemiology and Pathogenesis of Kawasaki Disease. Front Pediatr. 2018;6:374.

3. Shulman ST, Rowley AH. Kawasaki disease: insights into pathogenesis and approaches to treatment. Nat Rev Rheumatol. 2015;11(8):475-82.

4. Huang GY, Ma XJ, Huang M, Chen SB, Huang MR, Gui YH, Ning SB, Zhang TH, Du ZD, Yanagawa H, et al. Epidemiologic pictures of Kawasaki disease in Shanghai from 1998 through 2002. J Epidemiol. 2006;16(1):914.

5. Saguil A, Fargo M, Grogan S. Diagnosis and management of kawasaki disease. Am Fam Physician. 2015;91(6):365-71.

6. Wang S, Best BM, Burns JC. Periungual desquamation in patients with Kawasaki disease. Pediatr Infect Dis J. 2009;28(6):538-9.

7. Kim SHLH, Lee JS. Clinical Aspects of Periungual Desquamation in Kawasaki Disease. Iran J Pediatr. 2018;28(3):e59262.

8. Milstone LM. Epidermal desquamation. J Dermatol Sci. 2004;36(3):131-40.

9. Oliveira D, Borges A, Simoes M. Staphylococcus aureus Toxins and Their Molecular Activity in Infectious Diseases. Toxins (Basel) 2018, 10(6).

10. McFadden JP, Baker BS, Powles AV, Fry L. Psoriasis and streptococci: the natural selection of psoriasis revisited. Br J Dermatol. 2009;160(5):929-37.

11. Chong JH, Aan MKJ. An Atypical Dermatologic Presentation of a Child With Hand, Foot and Mouth Disease Caused by Coxsackievirus A6. Pediatr Infect Dis J. 2014;33(8):889.

12. Nag SS, Dutta A, Mandal RK. Delayed Cutaneous Findings of Hand, Foot, and Mouth Disease. Indian Pediatr. 2016;53(1):42-4.

13. Chasset F, Frances C. Cutaneous Manifestations of Medium- and Large-Vessel Vasculitis. Clin Rev Allergy Immunol. 2017;53(3):452-68.

14. Nassef C, Ziemer C, Morrell DS. Hand-foot-and-mouth disease: a new look at a classic viral rash. Curr Opin Pediatr. 2015;27(4):486-91. 
15. Ventarola D, Bordone L, Silverberg N. Update on hand-foot-and-mouth disease. Clin Dermatol. 2015;33(3):3406.

16. Managing scarlet fever. Drug Ther Bull 2017, 55(9):102.

17. Ladhani S, Joannou CL, Lochrie DP, Evans RW, Poston SM. Clinical, microbial, and biochemical aspects of the exfoliative toxins causing staphylococcal scalded-skin syndrome. Clin Microbiol Rev. 1999;12(2):224-42.

18. Yan X, Zhang ZZ, Yang ZH, Zhu CM, Hu YG, Liu QB. Clinical and Etiological Characteristics of Atypical HandFoot-and-Mouth Disease in Children from Chongqing, China: A Retrospective Study. Biomed Res Int. 2015;2015:802046.

19. Mathes EF, Oza V, Frieden IJ, Cordoro KM, Yagi S, Howard R, Kristal L, Ginocchio CC, Schaffer J, Maguiness S, et al. "Eczema coxsackium" and unusual cutaneous findings in an enterovirus outbreak. Pediatrics. 2013;132(1):e149-57.

20. Stevens DLBA: Impetigo, Erysipelas and Cellulitis. In: Streptococcus pyogenes: Basic Biology to Clinical Manifestations. edn. Edited by Ferretti JJ, Stevens DL, Fischetti VA. Oklahoma City (OK); 2016.

21. Kawasaki T. Kawasaki disease. Proc Jpn Acad Ser B Phys Biol Sci. 2006;82(2):59-71.

22. Michie C, Kinsler V, Tulloh R, Davidson S. Recurrent skin peeling following Kawasaki disease. Arch Dis Child. 2000;83(4):353-5.

\section{Figures}
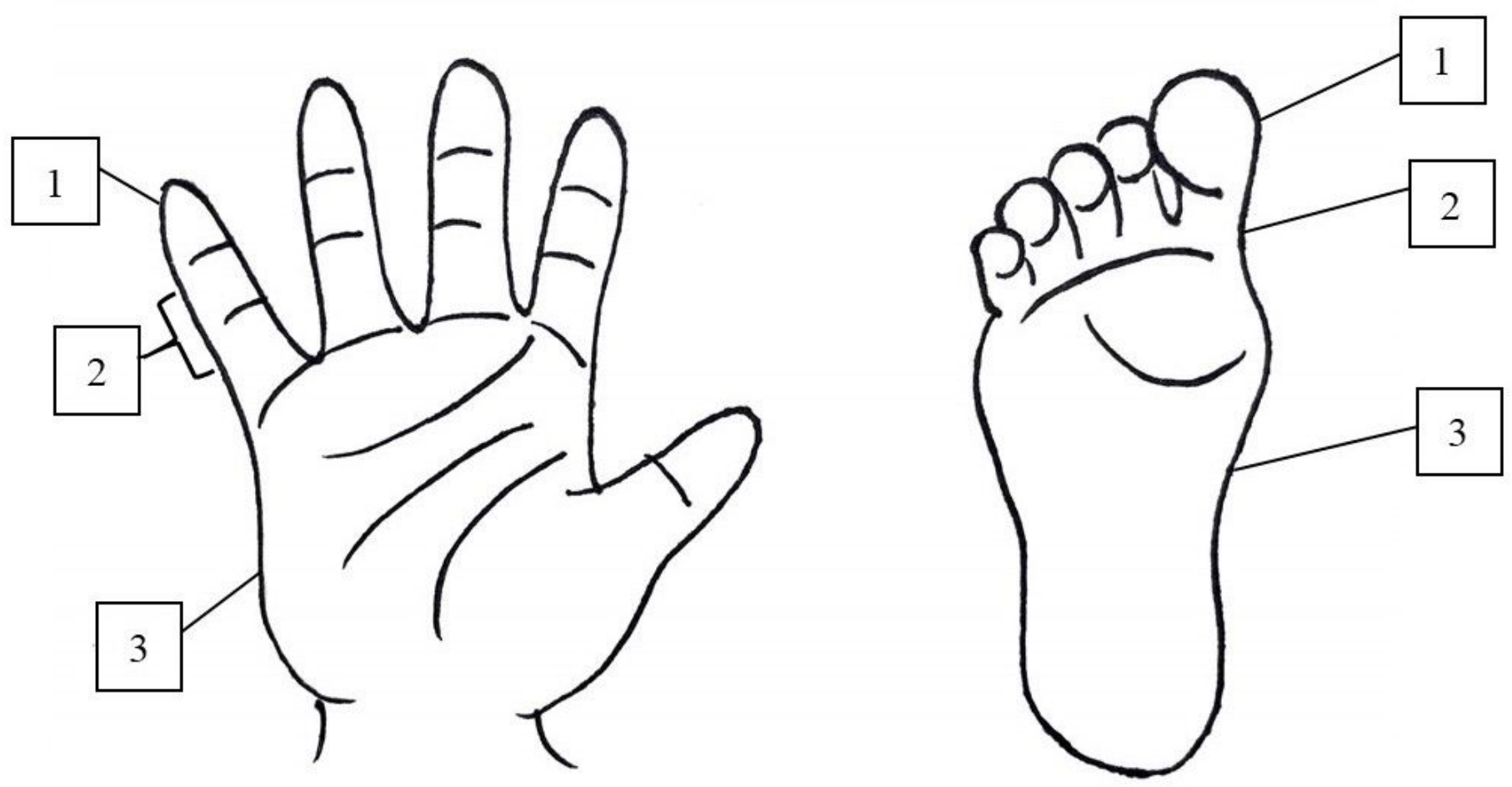

Figure 1

The illustration to identify the grade of desquamation 


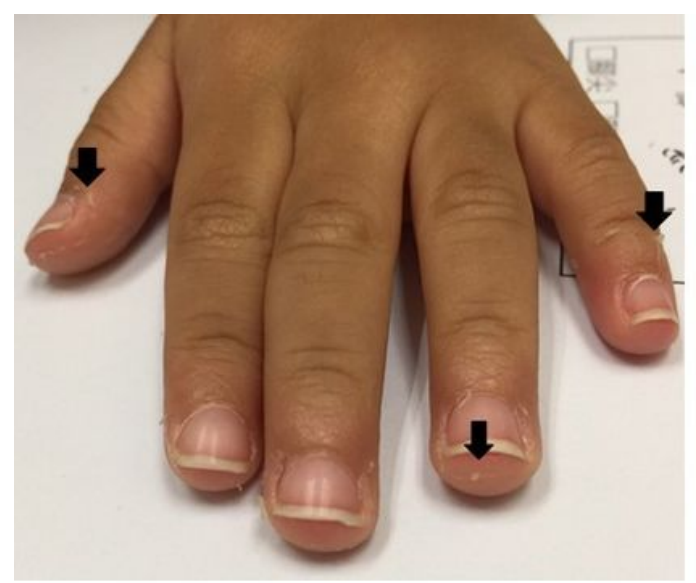

Figure 2a

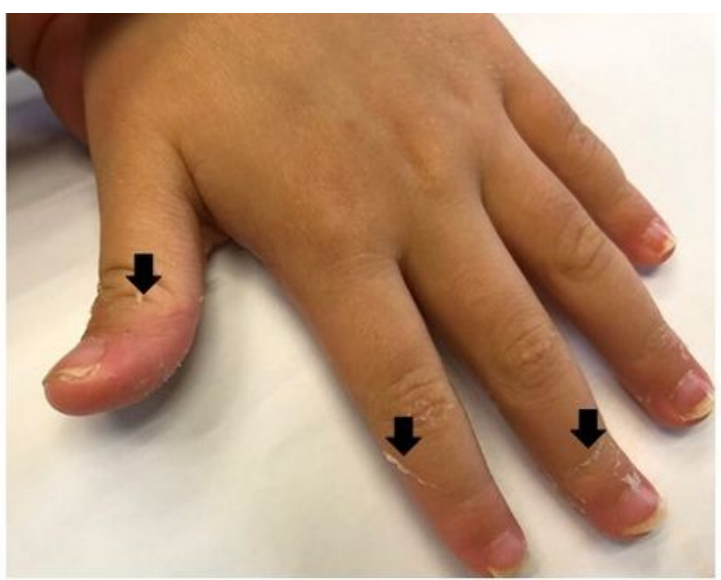

Figure $2 b$

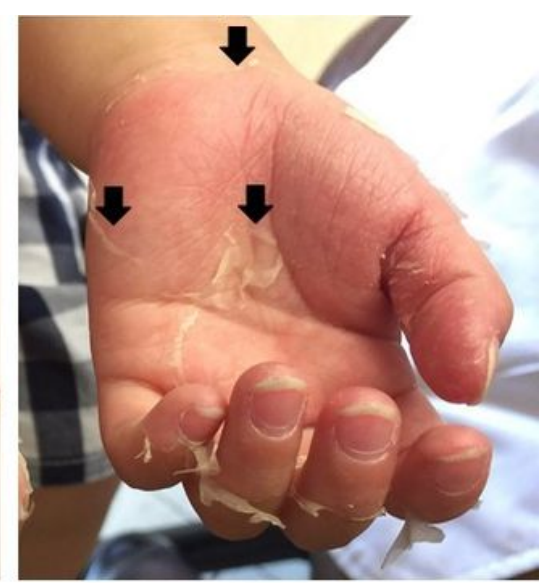

Figure 2c

\section{Figure 2}

The desquamation of hands; the black arrows point out the margin of peeling; a: grade 1; b: grade 2; c: grade 3

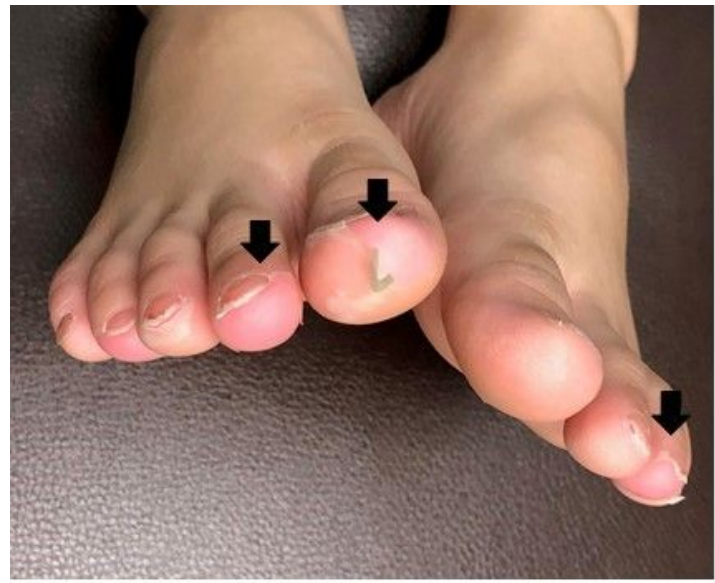

Figure $3 \mathrm{a}$

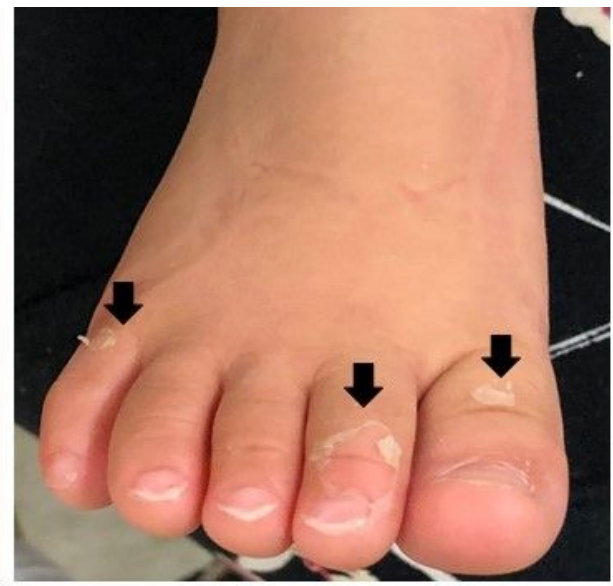

Figure $3 b$

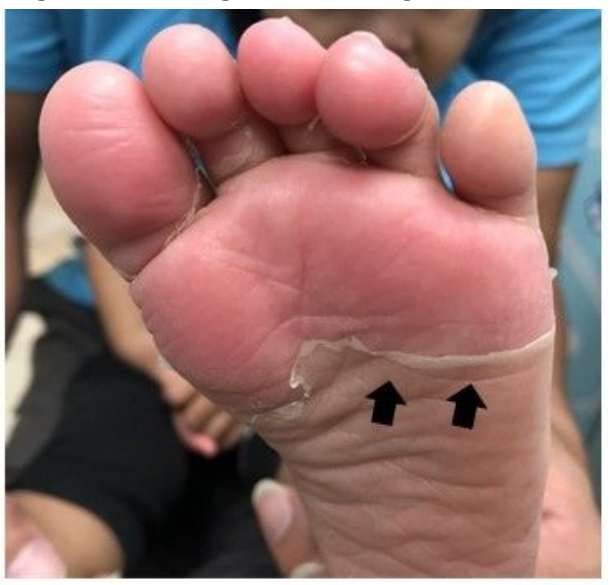

Figure 3c

Figure 3

The desquamation of feet; the black arrows point out the margin of peeling; a: grade 1; b: grade 2; c: grade 3 


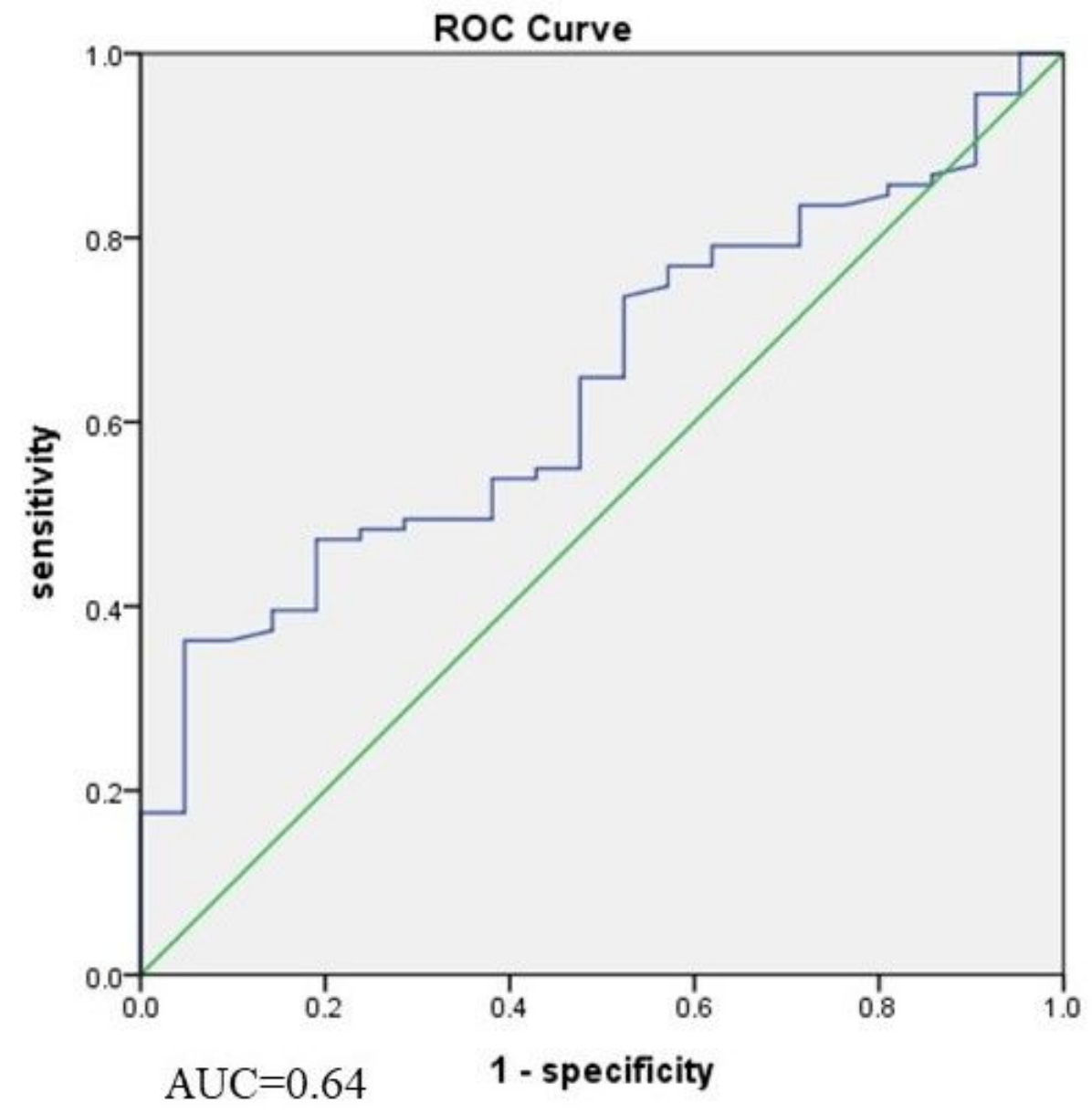

Figure 4

In the aspect of age, the area under the curve (AUC) of having hand desquamation 